32 Suzuki DA, Keller EL. The role of the posterior vermis of monkey cerebellum in smooth-pursuit eye movement control. I. Eye and head movement-related activity. $\mathcal{f}$ Neurophysiol 1988;59:1-18.

33 Lanman J, Bizzi E, Allum J. The coordination of eye and head movement during smooth pursuit. Brain Res 1978;153:39-53.

34 Bronstein AM, Mossman S, Luxon LM. The neck-eye reflex in patients with reduced vestibular and optokinetic function. Brain 1991;114:1-11.

35 Wilson VJ, Maeda M, Franck JI. Input from neck afferents to the cat flocculus. Brain Res 1975;89:133-8.

36 Takemori S, Cohen B. Loss of visual suppression of vestibular nystagmus after flocculus lesions. Brain Res 1974;72:213-24.

37 Robinson DA. Adaptive gain control of vestibuloocular reflex by the cerebellum. $f$ Neurophysiol 1976; 39.954-69.

38 Coats AC. Central electronystagmographic abnormalities. Arch Otolaryngol 1970;92:43-53.

39 Alpert $\mathrm{JN}$. Failure of fixation suppression: a pathologic effect of vision on caloric nystagmus. Neurology 1974;24:891-6.

40 Zee DS, Yee RD, Cogan DG, Robinson DA, Engel WK Ocular motor abnormalities in hereditary cerebellar ataxia. Brain 1976;99:207-34.

41 Dichgans J, von Reutern GM, Römmelt U. Impaired suppression of vestibular nystagmus by fixation in cerebellar and noncerebellar patients. Arch Psychiatry Neuro Sci 1978;226:183-99.

42 Llinás R, Walton K. Significance of the olivo-cerebellar system in compensation of ocular position following unilateral labyrinthecotomy. In: Baker R, Berthoz A, eds. Control of gaze by brain stem neurons. Amsterdam: Elsevier, 1977:399-408.

43 von Noorden GK, Preziosi TJ. Eye movement recordings in neurological disorders. Arch Ophthalmol 1966;76: 162-71.

44 Westheimer G, Blair SM. Functional organzation of primate oculomotor system revealed by cerebellectomy. Exp Brain Res 1974;21:463-72.

45 Baloh RW, Konrad HR, Honrubia V. Vestibulo-ocular function in patients with cerebellar atrophy. Neurology 1975;25:160-8.

46 Thurston SE, Leigh RJ, Abel LA, Dell'Osso LF. Hyperactive vestibulo-ocular reflex in cerebellar degeneration pathogenesis and treatment. Neurology 1987;37:53-7.

47 Rubin AM, Young JH, Milne AC, Scharz DWF, Fredrickson JM. Vestibular-neck integration in the vestibular nuclei. Brain Res 1975;96:99-102.

\section{A note on Heterochromia iridis}

"Her eyes are so adorable, but one of them is blue". . . . so runs an old Arthur Daley/Terence Christmas jingle. Sector pigmentation of one eye is common and is ascribed to persistence of the pupillary membrane. Irides of totally different colour are well known, harmless but rare. Aristotle named it heteroglaucous (Gk glaukos, sea-green). The Emperor Anastasios I probably had this condition and was generally called Dicorus. Alexander the Great was similarly affected. ${ }^{1}$
The association with deafness constitutes Waardenburg's syndrome and heterochromia iridis may be seen in congenital Horner's syndrome, the affected side being blue or depigmented in comparison with the normal side.

JMS PEARCE

1 Gladstone RM. Development and significance of heterochromia on the iris. Arch Neurol 1969;32:184-92. 